\title{
DOES EU ECONOMIC LAW PRECLUDE NATIONAL PROHIBITIONS OF SALES BELOW COST?
}

\author{
Bert Keirsbilck*
}

\begin{abstract}
This article discusses whether EU economic law precludes national prohibitions of sales below cost. Following an overview of the 1993 Keck and Mithouard judgment and the 2001 and 2002 Proposals for a Sales Promotions Regulation, the article will highlight the pre-emptive effect of the 2005 Unfair Commercial Practices Directive 2005/29 on national prohibitions of sales below cost. In addition, the so-called 'convergence rule' of the 2003 Antitrust Regulation 1/2003, which inter alia does not apply to national prohibitions of sales below cost, will be discussed. Finally, this article will open up new avenues for further research on whether EU economic law should preclude national prohibitions of sales below cost.
\end{abstract}

Keywords: National Prohibitions of Sales Below Cost; EU Law; Free Movement of Goods; Unfair Commercial Practices; Competition Law

\section{Setting the Scene: Does EU Economic Law Preclude National Prohibitions of Sales Below Cost?}

\section{National Prohibitions of Sales Below Cost}

In some Member States, sales below costs are prohibited. These national prohibitions aim to establish a certain threshold price under which undertakings are not allowed to sell except in a limited set of circumstances. However, the nature and scope of these national prohibitions vary widely (e.g. application of the prohibition to all retail sectors or only to certain firms or products; circumstances under which a sale below cost would be allowed even if the practice is generally prohibited; elements included in the calculation of 'costs', etc.).

In France, for example, Article L. 420-5 of the Commercial Code prohibits abusively low pricing as an 'anticompetitive practice', where the object or effect of such offers or practices is to exclude an undertaking from the market. The conditions of application of this prohibition are similar to those concerning predatory pricing (cost test), but its scope is limited to sales to final consumers, and it does not require proof of a dominant position. In addition, Article L. 442-2 of the Commercial Code, as amended by the 2008 Loi Chatel, prohibits resale below cost as a 'practice restricting competition'. The threshold was lowered in 2008 in order to allow deeper discounting by resellers without breaching Article L. 420-5 (abusively low pricing). ${ }^{1}$ In Belgium, Article 101 of the 2010 Market Practices and Consumer Protection Act contains a per se prohibition of sales below cost (retaking ex Article 41 of the 1991 Commercial Practices and Consumer Protection Act). Likewise, Spain and Portugal have certain unfair trade rules prohibiting sales below cost.

However, several Member States, including Ireland, Italy and the United Kingdom, have removed their rules concerning resale below cost in recent years.

Assistant Professor HUB, senior affiliated researcher KU Leuven.

The Attali report called for the removal of the prohibition of resale at loss (as amended by the 1996 'Loi Galland'). See Rapport de la Commission pour la libération de la croissance française, sous la présidence de Jacques Attali, 23 January 2008, available at <http://lesrapports.ladocumentationfrancaise.fr/ BRP/084000041/0000.pdf> 


\section{Outline}

The purpose of this article is to discuss whether EU economic law precludes national prohibitions of sales below cost. In the first section, the focus will be on the negative answer given by the European Court of Justice (ECJ) in the Keck and Mithouard judgment and on the answers of the European Commission in the Proposals for a Sales Promotions Regulation. In the second section, attention will be paid to the preemptive effect of the Unfair Commercial Practices Directive 2005/29 on national per se prohibitions of sales below cost, where they pursue objectives related to consumer protection. In addition, the exclusion of national prohibitions of sales below cost from the so-called 'convergence rule' of the Antitrust Regulation 1/2003 will be discussed. Finally, this article will open up new avenues for further research on whether EU economic law should preclude national prohibitions of sales below cost. In any case, there is an urgent need for the Union to take an unequivocal position on this matter.

\section{The Past Answers: No and Yes, Then No}

\subsection{Keck and Mithouard: No}

\section{Introduction}

It is well known that the ECJ ruled in Oosthoek that

legislation which restricts or prohibits certain forms of advertising and certain means of sales promotion may, although it does not directly affect imports, be such as to restrict their volume because it affects marketing opportunities for the imported products. The possibility cannot be ruled out that to compel a producer either to adopt advertising or sales promotion schemes which differ from one Member State to another or to discontinue a scheme which he considers to be particularly effective may constitute an obstacle to imports even if the legislation in question applies to domestic products and imported products without distinction. ${ }^{2}$

The Oosthoek criterion led to a flood of litigation where traders invoked the illegality of any (unfair) trade rules even where such rules did not have any greater impact on imported than on domestic products and merely reduced the overall volume of sales. This led to the possible subjection of any (unfair) trade rules to supervision under EU law and started to damage the image and legitimacy of the ECJ. Moreover, the ECJ's approach was not always consistent and when dealing with national rules restricting the circumstances in which goods may be marketed, Article 34 TFEU was sometimes interpreted narrowly, other times broadly. ${ }^{3}$

\section{Keck and Mithouard}

In Keck and Mithouard, the ECJ considered it necessary, in view of 'the increasing tendency of traders to invoke [Article 34 TFEU] as a means of challenging any rules whose effect is to limit their commercial freedom even where such rules are not aimed at products from other Member States', to 're-examine and clarify its case-law on this matter' ${ }^{4}$ In this case, the ECJ examined the compatibility with Article 34 TFEU of the French general prohibition on resale below cost. Mister Keck and Mister Mithouard, managers of two French supermarkets in Mundolsheim (close to the German border),

\footnotetext{
Case C-286/81, Criminal proceeding against Oosthoek's Uitgeversmaatschappij BV, [1982] ECR I-4575, para. 15.

See, with regard to this pre-Keck case law and different possible tests for Article 34 TFEU, W. Wils, 'The Search for the Rule in Article 30 EEC: Much Ado about Nothing?', 18 European Law Review 475 (1993).

4 Case C-286/81, Criminal proceeding against Oosthoek's Uitgeversmaatschappij BV, [1982] ECR I-4575, para. 14.
} 
were prosecuted in criminal proceedings for reselling beer and coffee in an unaltered state to consumers, at prices lower than their actual purchase price. Advocate General van Gerven presented two opinions with opposite results. ${ }^{5}$ The ECJ first observed that a general prohibition on resale below cost is not designed to regulate trade in goods between the Member States, but may, admittedly, be considered as 'legislation which restricts certain means of sales promotion and which restricts their volume' (Oosthoek). But the question remained whether such a possibility was sufficient to characterise the French prohibition in question as a measure having equivalent effect to a quantitative restriction. ${ }^{6}$ The ECJ argued that

in the absence of harmonisation of legislation, obstacles to free movement of goods which are the consequence of applying, to goods coming from other Member States where they are lawfully manufactured and marketed, rules that lay down requirements to be met by such goods (such as those relating to designation, form, size, weight, composition, presentation, labelling, packaging) constitute measures of equivalent effect prohibited by Article [34]. This is so even if those rules apply without distinction to all products unless their application can be justified by a public-interest objective taking precedence over the free movement of goods. ${ }^{7}$

By contrast, contrary to what has previously been decided, the application to products from other Member States of national provisions restricting or prohibiting certain selling arrangements is not such as to hinder directly or indirectly, actually or potentially, trade between Member States within the meaning of the Dassonville judgment, so long as those provisions apply to all relevant traders operating within the national territory and so long as they affect in the same manner, in law and in fact, the marketing of domestic products and of those from other Member States. ${ }^{8}$

The Keck proviso is actually a double discrimination test. Rules concerning selling arrangements are excluded so long as they are not discriminatory with regard to their application and with regard to their legal or factual effect. The ECJ indicated that the basic idea underlying the discrimination test is that of equal market access:

Provided that those conditions are fulfilled, the application of such rules to the sale of products from another Member State meeting the requirements laid down by that State is not by nature such as to prevent their access to

See Opinion of Advocate General van Gerven of 18 November 1992 (before the 2nd Chamber), Joined Cases C-267/91 and C-268/91, Criminal proceeding against Bernard Keck and Daniel Mithouard, [1993] ECR I-6097, stating that the French prohibition was basically suitable to ensure fair trading and consumer protection (para. 8) but did not satisfy the proportionality test (para. 9): 'The problem with a ban framed in general terms ... is, however, that use of the sales promotion method which it prohibits is also banned in trading situations which cannot be regarded as unfair, anti-competitive or detrimental to the consumer. ... In so far as it also covers those situations, a prohibition of sale at a loss framed in general terms therefore goes further than is necessary to achieve the aims allowed by Community law.'

See Opinion of Advocate General van Gerven of 28 April 1993 (before the full Court, to which the case was referred due to its importance), Joined Cases C-267/91 and C-268/91, Criminal proceeding against Bernard Keck and Daniel Mithouard, [1993] ECR I-6097, focusing on the question whether the French prohibition worked as an obstacle to intra-Union trade in the specific factual setting before the national court. He concluded (para. 13) that 'a statutory prohibition of resale at a loss is not incompatible with Article [34] of the EEC Treaty since it appears that the events at issue in the main proceedings occurred at the retail level, that is to say at a level in respect of which a recognised ground of justification may be invoked for the rules in question and that at that level there is no more than a purely hypothetical effect on trade between Member States and certainly no more than an hypothetical hindering of trade flows'. However, he added (para. 14) that 'that is not to say ... that France would not do well to amend its legislation to bring it more into conformity with Community law'.

Joined Cases C-267/91 and C-268/91, Criminal proceeding against Bernard Keck and Daniel Mithouard, [1993] ECR I-6097, para. 12-13.

7 Id., para. 15.

8 Id., para. 16. 
the market or to impede access any more than it impedes the access of domestic products. Such rules therefore fall outside the scope of Article [34] of the Treaty. ${ }^{9}$

Whereas Advocate General van Gerven in his two Opinions argued that the French prohibition of resale at a loss could, in some cases, impede access to the French market of imported products more than access of domestic products, the ECJ simply held that Article 34 TFEU 'is to be interpreted as not applying to legislation of a Member State imposing a general prohibition of resale at a loss' ${ }^{10}$

According to the ECJ, national requirements relating to 'selling arrangements', such as sales below cost, are by nature, as far as imported products are concerned, not 'such as to prevent their access to the market or to impede access more than they impede the access of domestic products'. They do not normally mean that (the intrinsic or extrinsic characteristics of) imported products must be adapted in order to satisfy the requirements of Member States of destination. Hence, the producer/supplier faces no (significant) additional costs, which would have the effect of impeding the imported product's access to the market or even, where those costs are prohibitive, of making access impossible. ${ }^{11}$

According to the ECJ, product requirements are by nature, as far as imported products are concerned, 'such as to prevent their access to the market or to impede access more than they impede the access of domestic products'. They mean that imported products lawfully manufactured and marketed in the Member State of origin must be adapted in order to suit the product requirements of the Member States of destination and must, as a result, satisfy the requirements of two different sets of legislation (contrary to the Cassis de Dijon principle of mutual recognition).

In opting for an overall assessment, the ECJ diverged from the Cassis de Dijon test. Indeed, at least as regards 'national provisions restricting or prohibiting certain sales arrangements', the ECJ no longer presumes that every national rule 'capable of hindering, directly or indirectly, actually or potentially, intra-[Union] trade' falls within the scope of Article 34 TFEU. ${ }^{12}$

\section{Conclusion}

The answer of Keck and Mithouard is no; EU law does not preclude national prohibitions of sales below cost, as long as they are not discriminatory with regard to their application and their legal or factual effect. ${ }^{13}$

\subsection{The Proposals for a Sales Promotions Regulation: Yes, Then No}

\section{Introduction}

As from the late 1990s, the Commission initiated legislative proceedings which were meant to lead to the adoption of a so-called Sales Promotions Regulation.

$\begin{array}{ll}9 & \text { Id., para. } 17 . \\ 10 & \text { Id., para. } 18 .\end{array}$

11 Opinion of Advocate General van Gerven of 16 March 1994, Joined Cases C-401/92 and C-402/92, Criminal proceedings against Tankstation 't Heukske vof and J.B.E. Boermans, [1994] ECR I-2199, para. 20.

12 Id., para. 24.

13 The ECJ confirmed the Keck judgment on the French prohibition of sales below cost in relation to the Belgian prohibition of sales yielding only a very low profit margin. See Case C-63/94, Groupement national des négociants en pomme de terre de Belgique v ITM Belgium SA and Vocarex SA, [1995] ECR I-2476. This is also settled in Belgian case law: see e.g. President of the Antwerp Commercial Court 19 June 2003, Jb. Hand. Med. at 380 (2003). 


\section{Original commission proposal}

In 2001, the Commission adopted a first Proposal for a Regulation on Sales Promotions in the Internal Market ('Original SP Proposal'). ${ }^{14}$ According to the Commission, the outcome of the assessment of the internal market barriers resulting from significant differences in national rules concerning commercial communications indicated that three types of provisions had to be established at the European level in order to remove these barriers: maximum harmonisation of certain (transparency) provisions concerning the use and commercial communication of sales promotions, abolishment of certain restrictions, and application of mutual recognition. The Commission was not in favour of a harmonised European ban on 'sales below cost' (defined as 'discounts consisting of a sale of a product or service by a retailer below the retailer's net invoice price inclusive of carriage, insurance and other delivery costs as well as tax') ${ }^{15}$ According to the Commission, the proportionality analysis suggested that the objective of preventing market destabilization, abuse of dominance and consumer deception could be realised by less restrictive measures such as harmonised transparency provisions. The protection against unfair competition and consumer protection could be achieved in a more effective and proportionate manner through specific information requirements than through prohibitions of sales below cost, which are in addition difficult to enforce.

The Commission proposed that suppliers would have to be informed ex-ante by their resellers, in conformity with contractual terms, of the possibility that their goods or services are to be resold at a loss. By being informed in this way, suppliers who are concerned that such operations could undermine their brand equity or give the impression that their products or services are of inferior quality would be able to set conditions in their initial supply contracts to prevent such outcomes or simply to refuse to enter into contract with the relevant resellers. In this way, economic detriment to small competitors of large retailers, who have sufficient lines of products to crosssubsidise such sales systematically, would also be avoided, as the large retailers would no longer be able to abuse their dominant positions in the retail market and drive out smaller competitors through such campaigns.

The Commission proposed that customers would have to be made aware of the real value of the good or service in order to ensure that they would be able to properly compare the real economic value of competing goods and services. Promoters would have to indicate in the relevant commercial communication whether a sale represents a sale below cost. This would ensure that consumers understand that the economic value of the product or service is greater than the discounted price that they are being offered to purchase it. Moreover, this transparent presentation of below cost sales would facilitate the application of competition policy rules against predatory pricing in that it would be easier to detect systematic operations of this type that could reflect the abuse of a dominant position by a reseller.

\section{Conclusion}

The answer of the SP Regulation, should the Original SP Regulation have been passed, would have been yes; EU law precludes national prohibitions of sales below cost.

\footnotetext{
14 Original Commission Proposal for a European Parliament and Council Regulation on Sales Promotions in the Internal Market, 2 October 2001, COM (2001) 546 final.

15 Article 2. See also Explanatory Memorandum: 'This definition is based on existing national definitions and is also consistent with jurisprudence of the Court in the field of competition rules (predatory pricing). A sales below cost is defined as a sale where the price at which the product or service is sold is lower than the net invoice price at which that retailer or wholesaler purchased the product or service from the relevant supplier. The net invoice price is the unit price on the invoice from the supplier or the wholesaler to the promoter including carriage, insurance or other costs and value added tax. The invoice and other costs used for the calculation should be dated the same day of the sales promotion or its commercial communication. Where no such invoice exists, the net invoice price should be based on the most recent invoice supplied to that promoter for such goods or services that are subject to the sales promotion'.
} 


\section{Amended Commission proposal}

In 2002, the Commission adopted an Amended Proposal for a Sales Promotions Regulation. The Commission accepted a number of European Parliament amendments which would contribute to 'a constructive compromise on the treatment of sales below costs' ${ }^{16}$ Basically, the EP wanted the Regulation to be 'without prejudice to national provisions governing sales or resales below cost', that is, 'without prejudice to the possibility for Member States or regulatory bodies to adopt specific measures which, in the interests of protecting consumers, supplier companies and competition, partially restrict the use and commercial communication of particular sales promotions such as sales below cost' ${ }^{17}$ The Commission took over this amendment in Article 3(3) of the Amended Proposal, according to which the Regulation would be 'without prejudice to national provisions governing sales or resales below cost'. This meant that national legislators would remain free to introduce or maintain prohibitions of sales below cost.

\section{Conclusion}

The answer of the SP Regulation, should the Amended SP Regulation have been passed, would have been no; EU law does not preclude national prohibitions of sales below cost. Interestingly, the revision clause of Article 7 provided that the comprehensive report on the application of the Regulation and of the impact of sales promotions law on both consumers and business would also have to contain 'a detailed evaluation of the Internal Market effects on the differing national prohibitions on sales below cost and an assessment of the impact of a potential liberalisation of such sales'.

\section{Repeal in 2006 of the Amended Commission Proposal for a Sales Promotions Regulation}

Ultimately, however, the legislative work on the Amended Commission Proposal was slowed down and finally stopped, awaiting the outcome of the work on the 2003 Commission Proposal for a Directive concerning unfair business-to-consumer commercial practices. ${ }^{18}$ The Amended Commission Proposal for a Sales Promotions Regulation was withdrawn in 2006.

\footnotetext{
16 Amended Commission Proposal for a Regulation on Sales Promotions in the Internal Market, 25 October 2002, COM (2002) 585 final.

17 European Parliament legislative resolution of 4 September 2002 on the proposal for a European Parliament and Council regulation on sales promotions in the Internal Market, A5-0253/2002, P5 $\mathrm{TA}(2002) 0400$, amendments 28 and 32, with the following justifications: 'In the report accompanying its proposal for a regulation the Commission confirms that sales below cost are legitimate. The legitimacy of sales promotions of this kind is not in question, but we feel that, in addition to specific conditions on transparency (requirement that the organisers of the promotion state clearly that the offer of a product or a service with a major reduction represents a sale below cost) to protect the consumer or the company supplying the products or services, consideration should be given to a further and no less damaging aspect of sales below cost, namely that they distort the conditions of competition to the detriment of other commercial companies, particularly small ones, as well as consumers. It is therefore proposed to amend the provisions of Article 3(2), first indent, of the proposal for a regulation, preventing Member States from imposing a general prohibition on the use or commercial communication of sales promotions, so that rules can be adopted at national level to regulate sales below cost in order to safeguard competition and protect supplier companies and consumers. ... Sales below cost should not be governed by Community law, but by national law in accordance with local circumstances. The subsidiarity principle should apply here'. See also Report of the Committee on Legal Affairs and the Internal Market of 10 July 2002 on the proposal for a European Parliament and Council Regulation concerning sales promotions in the Internal Market Committee on Legal Affairs and the Internal Market, A5-0253/2002, PE 312.784.

18 Commission Proposal for a Directive of the European Parliament and of the Council concerning unfair 'business-to-consumer' commercial practices in the Internal Market and amending directives 84/450/EEC, 97/7/EC and 98/27/EC (the Unfair Commercial Practices Directive), 18 June 2003, COM (2003) 356 final.
} 


\section{The Present Answers: Yes, Insofar as ... and No}

\subsection{Directive 2005/29/EC: Yes, Insofar as the National Prohibition Pursues Objectives Related to Consumer Protection}

\section{Introduction}

In 2005, the European legislator adopted Directive 2005/29/EC concerning unfair business-to-consumer commercial practices (hereafter 'UCP Directive'). ${ }^{19}$ This Directive establishes a single regulatory framework concerning unfair business-toconsumer commercial practices and is based on maximum harmonization. ${ }^{20}$ Does the UCP Directive have any (deregulatory) impact on national prohibitions of sales below cost? Following established ECJ case law on the Directive's pre-emptive impact (e.g. on the Belgian prohibition of discounts preceding seasonal sales), the following step-bystep analysis will lead to a conditional positive answer. On 19 July 2012, the commercial court of Gent (Belgium) lodged a reference for a preliminary ruling in the Euronics Belgium case in relation to the compatibility of the Belgian prohibition of sales below cost with the UCP Directive. ${ }^{21}$ It will be argued in the following paragraphs that the Directive must be interpreted as meaning that it precludes a national prohibition of sales below cost such as Article 101 of the Market Practices and Consumer Protection Act.

\section{Step 1 - Do sales below cost constitute B2C 'commercial practices'}

The first thing to assess is of course whether sales below cost constitute 'commercial practices' within the meaning Article 2(d) UCP Directive. It is well known that the Directive gives a particularly wide definition to the concept of 'business-to-consumer commercial practices': 'any act, omission, course of conduct or representation, commercial communication including advertising and marketing, by a trader, directly connected with the promotion, sale or supply of a product to consumers'. It seems that Member States such as Belgium and France, while agreeing on the Directive and slowing down the project for a Sales Promotions Regulation, were or even still are not fully aware of the fact that both the use and the commercial communication of B2C sales promotions are clearly covered by the Directive.

In the $V T B-V A B$ proceedings concerning the compatibility of the Belgian prohibition of joined offers to consumers, the Belgian and French Governments basically developed two arguments for the opposite view. They argued, principally, that neither the use nor the commercial communication of $\mathrm{B} 2 \mathrm{C}$ sales promotions constitute 'commercial practices' within the meaning of the UCP Directive as they were subject to the Amended Proposal for a Sales Promotions Regulation, and that the withdrawal of that Proposal (in 2006 only, one year after the adoption of the Directive) did not permit the inference that the Directive would now cover the use and commercial communication of B2C sales promotions previously covered by the Amended Proposal for a Sales Promotions Regulation. Belgium and France argued, in the alternative, that the use and commercial

\footnotetext{
19 Directive 2005/29/EC of the European Parliament and of the Council of 11 May 2005 concerning unfair business-to-consumer commercial practices in the internal market and amending Council Directive 84/450/ EEC, Directives 97/7/EC, 98/27/EC and 2002/65/EC of the European Parliament and of the Council and Regulation (EC) No 2006/2004 of the European Parliament and of the Council, OJ 2005 L 149.

20 The maximum harmonization character of the Directive has been confirmed in various ECJ judgments: Joined Cases C-261/07 and C-299/07, VTB-VAB NV v Total Belgium NV and Galatea BVBA v Sanoma Magazines Belgium NV, [2009] ECR I-2949, paras. 51-52; Case C-304/08, Zentrale zur Bekämpfung unlauteren Wettbewerbs eV v Plus Warenhandelsgesellschaft mbH, [2010] ECR I-217, para. 41; Case C-540/08, Mediaprint Zeitungs- und Zeitschriftenverlag GmbH \& Co KG v 'Österreich'-Zeitungsverlag GmbH, (2010) ECR 2010, I-10909, para. 30; Case C-288/10, Wamo BVBA v JBC NV and Modemakers Fashion NV, nyr, para. 33.

${ }_{21}$ Reference for a preliminary ruling from the Rechtbank van Koophandel te Gent (Belgium) lodged on 19 July 2012, Case C-343/12, Euronics Belgium CVBA v Kamera Express BV \& Kamera Express Belgium $B V B A$.
} 
communication of $\mathrm{B} 2 \mathrm{C}$ sales promotions only fall within the scope of application of the Directive, where, additionally, they are unfair within the meaning of its grand general clause.

However, the Advocate General Trstenjak and the ECJ rightly rejected these two arguments in the following manner. First, it was argued that both the commercial communication and the use of $\mathrm{B} 2 \mathrm{C}$ sales promotions constitute 'commercial practices' within the meaning of the Directive, as they 'clearly form part of an operator's commercial strategy and relate directly to the promotion thereof and its sales development ${ }^{\prime} ;{ }^{22}$ by no later than the date of withdrawal of the Amended Proposal for a Sales Promotions Regulations (in 2006, at a time when the period for the transposition of the Directive was still running), the national legislators should have examined, if necessary, to what extent the scope of the Directive would also apply to fields previously covered by the Amended Proposal for a Sales Promotions Regulations. In my view, business-to-consumer sales below cost undeniably constitute 'business-to-consumer commercial practices' within the meaning of the Directive and the VTB-VAB judgment. Moreover, the fact that the Amended Proposal for a Sales Promotions Regulations is without prejudice to national prohibitions of sales below cost, is irrelevant, since it was repealed in 2006, well before the end of the transposition deadline of the Directive. Second, the argument that only unfair business-to-consumer commercial practices fall within the scope of application of the Directive was rightly disqualified in $V T B-V A B$ as circular reasoning, stemming from an equation of the Directive's scope of application with the conditions of application of its general clause. ${ }^{23}$

It is worth noting that the Belgian legislator developed an additional argument for the view that the Belgian prohibition of $\mathrm{B} 2 \mathrm{C}$ sales below cost falls outside the scope of the Directive. When transposing the Directive in 2007, the Belgian legislator argued, in the further alternative, that the Directive covers only commercial communications of sales below cost, not the use of sales below cost as such. The Directive was said to be without prejudice to national prohibitions on the use of sales below cost or to any 'fundamental requirements' to be met by such sales, such as Article 41 of the 1991 Commercial Practices and Consumer Protection Act. When drafting the new Market Practices and Consumer Protection Act in 2010, the Belgian legislator argued again that price setting below cost, as prohibited by Article 101 of that Act, is not a 'commercial practice' within the meaning of the Directive, on the ground that price setting as such, whether below cost or not, represents nothing but an internal business decision. The Belgian legislator seemed to argue that commercial communications (to the public) that prices of particular goods are below cost, constitute commercial practices, while sales below cost as such do not. ${ }^{24}$

Yet, it is evident that the distinction between the prohibition of certain commercial communications on business practices on the one hand and the prohibition of the use of certain business practices, or the regulation of their 'basic conditions', is artificial and in line neither with the Directive nor with Belgian unfair trade law itself. As mentioned, the Directive's definition of 'commercial practices' includes not only 'commercial communication including advertising and marketing' but also 'any act, omission, course of conduct or representation, by a trader, directly connected with the promotion, sale or supply of a product to consumers'. Similarly, the Commission Proposals for a Sales Promotions Regulation deliberately covered both the use and the commercial

\footnotetext{
22 Joined Cases C-261/07 and C-299/07, VTB-VAB NV v Total Belgium NV and Galatea BVBA v Sanoma Magazines Belgium NV, [2009] ECR I-2949, paras. 49-50; Case C-304/08, Zentrale zur Bekämpfung unlauteren Wettbewerbs eV v Plus Warenhandelsgesellschaft mbH, [2010] ECR I-217, paras. 36-37; Case C-540/08, Mediaprint Zeitungs- und Zeitschriftenverlag GmbH \& Co KG v 'Österreich'-Zeitungsverlag GmbH, [2010] ECR 2010, I-10909, paras. 17-18; Case C-288/10, Wamo BVBA v JBC NV and Modemakers Fashion NV, nyr, paras 30-31.

23 See B. Keirsbilck, The New European Law of Unfair Commercial Practices and Competition Law (2011), at 231 et seq.

${ }_{24}$ See H. De Bauw, 'De gevolgen van het "koppelverkooparrest" van het Hof van Justitie van 23 april 2009 voor de sperperiode en enkele andere regels', 2008 Jaarboek Handelspraktijken en Mededinging 331 at $347-348$.
} 
communication of sales promotions, as use and communication cannot be isolated from each other. Likewise, Belgian unfair trade law traditionally simultaneously regulates the use and the commercial communication of 'market practices'.

Furthermore, the Belgian legislator argued that the Belgian prohibition of sales below cost must be considered as a national contract law rule, to which the Directive is, pursuant to Article 3(2), without prejudice. ${ }^{25}$ From this perspective, a retail price is primarily seen as the individually negotiated consideration for the transfer of the property of the good from the business to the consumer. Under this reading, the Belgian prohibition is seen as a contract law rule prohibiting the conclusion of below cost $\mathrm{B} 2 \mathrm{C}$ sales contracts, and it is stressed that according to Belgian case law, infringements of that prohibition may result in the invalidity of the contract at issue. Hence, the prohibition is said to fall outside the scope of the Directive.

However, retail prices (whether below cost or not) are very often not individually negotiated but rather offered on a take-it-or-leave-it basis. Unfair trade law extensively regulates pricing practices, as they may have a substantial impact on the market by addressing or reaching a (large) number of consumers and influencing if not materially distorting their economic behaviour. ${ }^{26}$ The Belgian prohibition of $\mathrm{B} 2 \mathrm{C}$ sales below cost has a similar collective dimension and prohibits the use and commercial communication of below cost pricing practices directly connected with the promotion of goods to consumers. In my view, the Belgian prohibition thus pertains to a commercial practice falling within the scope of the Directive. This conclusion cannot be called into question by the fact that infringements of that prohibition may result in the invalidity of the contract at issue. Article 3(2) of Directive 2005/29 must be interpreted as merely seeking to ensure that undesirable overlapping of the Directive and European or national contract law instruments does not occur at the level of legal consequences. ${ }^{27}$

Hence, national prohibitions of sales below cost fall within the scope of the Directive, in so far as they apply to B2C relationships, and they fall outside the scope of the Directive, in so far as they apply to B2B relationships.

\section{Step 1bis - Do prohibitions of sales below cost pursue objectives related to consumer protection?}

Upon finding that a national measure concerns a 'commercial practice' within the meaning of the Directive, the next step is to determine whether that measure pursues objectives relating to consumer protection. A measure concerning a 'commercial practice' falls outside the scope of the Directive, if it does not pursue consumer protection objectives. It is settled case law since the ECJ judgments in Plus ${ }^{28}$ and Mediaprint ${ }^{29}$ and the ECJ orders in Wamo $^{30}$ and Inno, ${ }^{31}$ that the statement in recitals 6 and 8 that the UCP Directive "neither covers nor affects the national laws on unfair commercial practices which harm only competitors' economic interests' should be interpreted as meaning that the Directive is without prejudice to any national measure concerning a 'commercial practice' that only has competitor protection objectives. ${ }^{32}$ A national measure regulating

\footnotetext{
25 See also H. De Bauw, 'De impact van de richtlijn oneerlijke handelspraktijken op de regeling van de verkooppromoties onder de WHPC', 2006 DCCR 3, at 19; De Bauw, above n. 24, at 347-348.

26 See also J. Glöckner, 'The Scope of Application of the UCP Directive - I Know What You Did Last Summer', 41 IIC 570, at 589 (2010), who regrets that the collective protective purpose of the Directive has not been adequately expressed in the definition of commercial practice.

27 See Opinion of Advocate General Trstenjak, Case C-453/10, Jana Pereničová, Vladislav Perenič v SOS financ spol. s r. o., nyr, paras. 89-90.

${ }_{28}$ Case C-304/08, Zentrale zur Bekämpfung unlauteren Wettbewerbs eV v Plus Warenhandelsgesellschaft $m b H$, [2010] ECR I-217, paras. 38-39.

29 Case C-540/08, Mediaprint Zeitungs- und Zeitschriftenverlag GmbH \& Co KG v 'Österreich'Zeitungsverlag GmbH, [2010] ECR 2010, I-10909, paras. 21-22.

30 Case C-288/10, Wamo BVBA v JBC NV and Modemakers Fashion NV, nyr, para. 20.

31 Case C-126/11, INNO NV v Unie van Zelfstandige Ondernemers VZW (UNIZO), Organisatie voor de Zelfstandige Modedetailhandel VZW (Mode Unie), Couture Albert BVBA, nyr, para. 22.

${ }^{32}$ According to an alternative interpretation of recitals 6 and 8, the UCP Directive would neither cover nor affect national provisions regulating or prohibiting a commercial practice without actually having any consumer protection effect. See on this alternative interpretation in relation to the Belgian prohibition
} 
or prohibiting a commercial practice with the dual aim of protecting competitors and consumers falls within the scope of the UCP Directive. This is also the view promoted by the Commission in its UCP Guidance. ${ }^{33}$ In order to establish whether a national provision (also) aims at protecting consumers, the general purpose of the law, the background and genesis of the measures in question, the preparatory works and academic comments should be taken into account. ${ }^{34}$ In the Wamo and Inno orders concerning the incompatibility of the Belgian prohibition of discounts preceding seasonal sales, the ECJ confirmed that the relevant question, upon finding that the national prohibition pertains to a 'commercial practice' within the meaning of the directive, is whether 'the national provision ... pursues objectives relating to consumer protection so that it comes within the scope of the Unfair Commercial Practices Directive'.$^{35}$

According to the European Commission, national prohibitions of selling below cost fall outside the scope of the UCP Directive, if the sole rationale is to ensure fair competition in the market space. Such national prohibitions fall within the scope of the Directive (and are precluded by that Directive), insofar as they pursue objectives relating to consumer protection (e.g. protection against bait practices). ${ }^{36}$

In this respect, a close examination of the legislative proceedings leading to the adoption of the Belgian prohibition of sales below cost demonstrates that the prohibition of ex Article 41 Commercial Practices and Consumer Protection Act was introduced in order to protect both the economic interests of competitors and of consumers. Undoubtedly, the main objective was to protect small retailers against big chain stores, who have sufficient lines of products to cross-subsidize sales below cost systematically, and to ensure fair competition. However, the legislator also sought to protect consumers against businesses selling selected goods below cost, thereby attracting consumers who will make up for the losses on highlighted products with additional purchases of profitable goods. ${ }^{37}$

As mentioned, Article 101 of the 2010 Market Practices and Consumer Protection Act retakes Article 41 of the repealed 1991 Commercial Practices and Consumer Protection Act. Not unsurprisingly, the proponents of the Belgian prohibition of sales below cost may now argue that from 2010 the Belgian prohibition no longer seeks to protect the

of discounts preceding seasonal sales B. Keirsbilck, 'De invloed van het Europees recht op het Belgisch handelspraktijken- en belendende verbintenissenrecht', in I. Samoy, E. Terryn and V. Sagaert (eds.), De invloed van het Europese recht op het Belgische privaatrecht (2012) 591; H. Dewulf, B. Keirsbilck and E. Terryn, 'Overzicht van rechtspraak - Algemeen handelsrecht en handelspraktijken', 48 TPR 921, at 11171123 (2011).

33 Commission Staff Working Document, Guidance on the implementation/application of Directive 2005/29/EC on unfair commercial practices, SEC(2009) 1666, 3 December 2009, 14: 'National rules regulating commercial practices ... for which the sole rationale is to ensure fair competition in the market space, do not fall within the scope of the Directive. ... Where consumers' and competitors' interests coincide and national measures regulate a practice with the dual aim of protecting consumers and competitors, such national measures are covered by the Directive.' See also D. Gol, 'Des pratiques du commerce aux pratiques du marché: la loi du 6 avril 2010‘, in N. Thirion (ed.), Actualités en matière de pratiques du marché et protection du consommateur (2010) 53, at 98; E. Terryn, 'Koppelverkoop en andere per se verboden in de Handelspraktijkenwet (toekomstige Wet Marktpraktijken en Consumentenbescherming) na het VTB-VAB-arrest van het Hof van Justitie', $73 R W$ 1242, at 1249 (2010).

34 See Commission Staff Working Document, Guidance on the implementation and application of Directive 2005/29/EC concerning unfair commercial practices, SEC (2009) 1666, 3 December 2009, 15 and 16, clearly drawing inspiration from the Opinion of Advocate-General Trstenjak of 3 September 2009, Case C-304/08, Zentrale zur Bekämpfung unlauteren Wettbewerbs eV v Plus Warenhandelsgesellschaft $m b H$, [2010] ECR I-217, para. 66 and from her Opinion of 24 March 2010, Case C-540/08, Mediaprint Zeitungs- und Zeitschriftenverlag GmbH \& Co KG v 'Österreich'-Zeitungsverlag GmbH, [2010] ECR I-10909, paras. 55-58.

35 Case C-288/10, Wamo BVBA v JBC NV and Modemakers Fashion NV, nyr, para. 20; Case C-126/11, INNO NV v Unie van Zelfstandige Ondernemers VZW (UNIZO), Organisatie voor de Zelfstandige Modedetailhandel VZW (Mode Unie), Couture Albert BVBA, nyr, para. 22. See also J. Vannerom, 'Case Wamo: And the Question Remains ... Who Is (Actually) Protected?', 2012 REDC 151; B. Akkermans, 'Belgian Prohibition on Sales Periods Outside the Legally Mentioned Periods', 18 MJ 411, at 411-413 (2011).

36 Commission Staff Working Document, Guidance on the implementation/application of Directive 2005/29/EC on unfair commercial practices, SEC (2009) 1666, 3 December 2009, 14.

37 See e.g. President of the Liège Commercial Court 17 July 2008, Jb.Hand.Med. at 250 (2008). 
economic interests of consumers. However, this argument is not very convincing, ${ }^{38}$ as there are no indications that in 2010 the Belgian legislator has renounced the consumer protection objectives when deciding to retake the prohibition. In this respect, it is worth noting that the preliminary question by the Belgian commercial court in the Euronics Belgium case explicitly states that 'Article 101 [of the Market Practices and Consumer Protection Act] ..., inter alia, is intended to protect the interests of consumers'. Even if the Belgian prohibition of sales below cost was introduced first and foremost with a view to protect the economic interests of small retailers, it falls within the scope of the Directive, as it does not exclusively seek to protect those interests. ${ }^{39}$

Hence, national prohibitions of business-to-consumer sales below cost fall within the scope of the Directive, insofar as they pursue objectives related to consumer protection and do not exclusively seek to protect other (economic) interests. ${ }^{40}$ The inevitable conclusion is that the UCP Directive precludes the Belgian prohibition of sales below cost ${ }^{41}$ just like it precludes the Belgian prohibition of discounts preceding seasonal sales. ${ }^{42}$

It is worth noting that not all national prohibitions of sales below cost may fall outside the scope of the Directive. For each and every national prohibition of sales below cost one should examine whether the national protective purpose of the measure includes consumer protection or not. This means that similar prohibitions may fall outside the scope of the Directive in one Member State and inside the scope of the Directive in another. Thus, it may seem a mission impossible to autonomously define the (preemptive) scope of the Directive, not only in relation to national prohibitions of sales below cost, but also in relation to, e.g., national prohibitions of discounts preceding seasonal sales. ${ }^{43}$

38 Compare Brussels Court of Appeal 17 January 2012, not publ., arguing that prohibition of discounts preceding seasonal sales was maintained in Article 32 of the 2010 Market Practices and Consumer Protection Act with the double aim of consumer protection and competitor protection, which inspired the introduction of that prohibition in 1985 in Article 53 of the Commercial Practices and Consumer Protection Act.

39 Reference for a preliminary ruling from the Rechtbank van Koophandel te Gent (Belgium) lodged on 19 July 2012, Euronics Belgium CVBA v Kamera Express BV \& Kamera Express Belgium BVBA, Case C-343/12. See similarly, as regards the compatibility of Austrian rules concerning liquidation sales, Opinion of Advocate-General Trstenjak of 6 September 2012, Case C-206/11, Georg Köck / Schutzverband gegen unlauteren Wettbewerb, nyr, paras. 37-39.

40 See also B. Keirsbilck and J. Stuyck, 'Een kritische analyse van de Wet Marktpraktijken en Consumentenbescherming', 116 TBH 739 (2010). Compare Gol, above n. 33, at 102 and 104; A. Puttemans and R. Gyory, 'Qu'y a-t-il de neuf dans la nouvelle loi sur les pratiques du marché et la protection du consommateur (ex-LPCC) et qu'en est-il de sa compatibilité avec le droit européen?', 2010 BFR 3, at 29. ${ }_{41}$ See also Keirsbilck and Stuyck, above n. 40; Dewulf, Keirsbilck and Terryn, above n. 32, at 1117-1123. 42 Interestingly, the national courts which made the reference for a preliminary ruling in the Wamo and Inno cases, ruled subsequently that the Belgian prohibition of announcements of discount preceding seasonal sales (Article 53 of the 1991 Commercial Practices and Consumer Protection Act) fall within the scope of Directive 2005/29, as this national measure pertains to a 'commercial practice' and pursues objectives relating to consumer protection and that this measure is incompatible with the Directive, as it prohibits a particular commercial practice per se notwithstanding that this practice is not referred to in the blacklist of the directive. See President of the Dendermonde Commercial Court 20 June 2012, not publ. Court Cassation 2 Nov. 2012, not publ. See also B. Keirsbilck, 'Sperperiode is dood en moet dringend begraven worden', De Juristenkrant, 27 June 2012.

See also Press release of the European Commission, Consumers: the European Commission asks Belgium and France to comply with EU rules on unfair practices, available at http://europa.eu/rapid/pressrelease_IP-11-1096_en.htm. See also Action brought on 13 September 2012, European Commission / Belgium, case $\mathrm{C}-42 \overline{1} / 12$.

${ }_{43}$ See, however, the overall analysis in the Original Commission Proposal for a European Parliament and Council Regulation on Sales Promotions in the Internal Market, 2 October 2001, COM (2001) 546 final, at 16: 'A few Member States ban discounts for a specified period prior to seasonal sales. Both consumer protection and the protection against unfair competition are invoked to justify these bans. These bans are held to allow consumers to distinguish clearly between the pre-sales period (with no advertised discounts) and the seasonal sales periods (with considerable discounts). However, ... they are counterproductive to protecting their invoked public interest objectives and should be replaced by clear transparency provisions on discounts.' See Article 3(1) Original and Amended Commission Proposal: 'Member States or non-public regulatory bodies shall not impose: - a prohibition on discounts preceding seasonal sales.' 
Step 2 - sales below cost have not been prohibited per se by the UCP Directive

As selling below cost does not appear in Annex I to the UCP Directive, it cannot be prohibited in all circumstances, but can be prohibited only following a specific assessment allowing the unfairness of those practices to be established. ${ }^{44}$ In the light of the content and the general scheme of the provisions of the Directive, the UCP Directive precludes any national provision which establishes a presumption of unlawfulness of sales below cost and prohibits, generally and pre-emptively, sales below cost, without any verification of their unlawfulness in the light of the criteria laid down in Articles 5 to 9 .

Besides, the Directive provides for adequate and sufficient consumer protection against bait advertising. In addition, competition law provides for adequate and sufficient protection against predatory pricing. ${ }^{45}$

Hence, national consumer protection rules prohibiting business-to-consumer sales below cost are contrary to the Directive, in so far as they generally outlaw sales below cost, whereas the Directive does not blacklist such sales practices.

\section{Conclusion - Yes, insofar as}

Hence, the answer of the Unfair Commercial Practices Directive is yes; EU law precludes national prohibitions of sales below cost insofar as the particular national prohibition pursues objectives related to consumer protection.

Strangely enough, the positive integration wave of the UCP Directive goes further than the negative integration wave of Keck and Mithouard: the UCP Directive precludes certain national rules relating to selling arrangements for goods (commercial practices), where they do not exclusively seek to protect the economic interests of competitors; yet, under the Keck conditions, they used to fall outside the scope of Article 34 TFEU. The presumption of the Directive is the opposite to that in Keck: illegality of national rules restricting or prohibiting certain commercial practices and a presumption in favour of free trade. ${ }^{46}$

\subsection{Regulation (EC) No. 1/2003: No}

\section{Introduction}

Regulation $1 / 2003$ on the implementation of the rules on competition laid down in Articles 101 and 102 TFEU is also known as the Modernisation Regulation. ${ }^{47}$

\section{Convergence rule}

Article 3(2), first sentence, Regulation 1/2003 states,

\footnotetext{
44 Joined Cases C-261/07 and C-299/07, VTB-VAB NV v Total Belgium NV and Galatea BVBA v Sanoma Magazines Belgium NV, [2009] ECR I-2949, paras. 53 et seq.; Case C-304/08, Zentrale zur Bekämpfung unlauteren Wettbewerbs eV v Plus Warenhandelsgesellschaft mbH, [2010] ECR I-217, paras. 42 et seq.; Case C-540/08, Mediaprint Zeitungs- und Zeitschriftenverlag GmbH \& Co KG v 'Österreich'Zeitungsverlag GmbH, [2010] ECR 2010, I-10909, paras. 31 et seq.; Case C-288/10, Wamo BVBA v JBC NV and Modemakers Fashion NV, nyr, paras. 34 et seq.

45 See Keirsbilck and Stuyck, above n. 40.

46 See also G. Davies, 'Can Selling Arrangements Be Harmonised?', 30 European Law Review 370, at 371 (2005); A. Pliakos and G. Anagnostaras, 'Harmonising National Laws on Commercial Practices: Sales Promotions and the Impact on Business-to-Business Relations', 35 European Law Review 425, at 429-430 (2010); G. Anagnostaras, 'The Unfair Commercial Practices Directive in Perspective: from Legal Disparity to Legal Complexity?', 47 CML Rev 147, at 156 (2010); Keirsbilck, above n. 23, at 232; C. Barnard, 'What the Keck? Balancing the Needs of the Single Market with State Regulatory Autonomy in the EU (and the US)', 2012 REDC 2; P. Oliver, 'The Scope of Article 34 TFEU after Trailers', 2012 REDC 313.

${ }_{47}$ Regulation (EC) No $1 / 2003$ of 16 December 2002 on the implementation of the rules on competition laid down in Arts 81 and 82 of the Treaty, OJ 2003 L 1/1.
} 
The application of national competition law may not lead to the prohibition of agreements, decisions by associations of undertakings or concerted practices which may affect trade between Member States but which do not restrict competition within the meaning of Article 81(1) of the Treaty, or which fulfil the conditions of Article 81(3) of the Treaty or which are covered by a Regulation for the application of Article 81(3) of the Treaty. ... ${ }^{48}$

This 'convergence rule' means that the application of national competition laws to agreements, decisions or concerted practices may not lead to the prohibition of such agreements, decisions and concerted practices if they are not also prohibited under Article 101 TFEU. Application of Article 101 TFEU to a particular case precludes inconsistent application of national competition law to that case. Stricter national competition laws can be applied only to local or regional cases which do not affect trade between Member States. ${ }^{49}$ The convergence rule seeks to create a level-playing field by providing for a single standard of assessment which allows undertakings to design EUwide business strategies without having to check them against all the relevant national sets of competition rules. It is a directly applicable rule that can be relied on before national courts, which implies that any measure adopted in breach of that rule would be inapplicable and unenforceable. ${ }^{50}$

In its current wording, the obligation of convergence covers only the application of national competition law to agreements, concerted practices and decisions by associations of undertakings within the meaning of Article 101 TFEU. Member States remain free to adopt or maintain stricter national competition laws than Article 102 TFEU in order to prohibit or sanction unilateral conduct. ${ }^{51}$ Article 3(2), second sentence, Regulation 1/2003 states,

Member States shall not under this Regulation be precluded from adopting and applying on their territory stricter national laws which prohibit or sanction unilateral conduct engaged in by undertakings. ${ }^{52}$

This exception from the level-playing field implies that undertakings doing crossborder business in the internal market may be subjected to a variety of standards as to their unilateral behavior. According to the Commission, 'the prohibition rule of Article [102], in so far as it applies to unilateral conduct, constitutes only a minimum standard that must be applied throughout the Community' ${ }^{53}$ The Commission identified certain categories of national provisions of the type referred to in Article 3(2), second sentence, including national prohibitions of 'resale below cost' or 'resale at loss', typically based on a similar economic rationale as the prohibition of predatory pricing (abuse of dominance) but not requiring proof of dominance..$^{54} \mathrm{~A}$ study commissioned by the European Commission is in the pipeline (COMP/2009/A4/021). This study will inter alia (i) provide an exhaustive overview of stricter national provisions on unilateral conduct in the 27 Member States, based on an assessment of the aim and the contents of the national provisions and, therefore, being independent of whether these provision are included in national competition laws and (ii) give a clear explanation of the impact which stricter national competition law provisions on unilateral conduct have on undertakings.

No

For the time being, the answer of the Modernisation Regulation is no; EU law does not preclude national prohibitions of sales below cost.

48 See also Recital 8 Regulation 1/2003.

49 Communication Report of 29 April 2009 on the functioning of Regulation 1/2003, COM (2009) 206 final, 6.

50 Commission Staff Working Paper of 29 April 2009 accompanying the Report on Regulation 1/2003, (SEC (2009) 574 final, at 48-49.

51 Report on Regulation $1 / 2003,6$.

52 See also Recital 8 Regulation 1/2003.

53 Staff Working Paper on Article 3 Proposal 1/2003, 19

54 Staff Working Paper accompanying the Report on Regulation 1/2003, 52-53. 


\section{Epilogue: Should EU Economic Law Preclude National Prohibitions of Sales Below Cost?}

\section{Report on the functioning of Regulation 1/2003}

In the 2009 Report on the functioning of Regulation 1/2003, the Commission stated that the exclusion of unilateral conduct from the scope of the convergence rule is a matter which should be further examined. ${ }^{55}$ The divergence of standards regarding unilateral conduct has been criticised by the business and legal communities, considering that diverging standards fragment business strategies that are typically formulated on a panEuropean or global basis. ${ }^{56}$ The Commission also stated that such per se prohibitions may result in price increases and loss of consumer welfare. ${ }^{57}$ In my view, the Commission should consider to extend the convergence rule to national laws covering unilateral conduct. ${ }^{58}$ National prohibitions of resale below cost would then be precluded by EU competition law.

\section{Report on the transposition and application of Directive 2005/29/EC}

The Commission is expected to publish a Report on the application of Directive 2005/29/EC on Unfair Commercial Practices in the near future. One of the question of the Commission's Consultation paper was ' 11 . Do you consider that there are any legislative gaps in certain areas (e.g. sales promotions) which have affected the effective enforcement against certain unfair commercial practices? Should specific commercial practices be excluded from the scope of the Directive?' In my view, the European legislator should consider to extend the scope of application of the Directive to cover, in principle, all commercial practices, whether B2C or B2B, irrespective of the national legislative aim of rules concerning commercial practices. This could be combined with some specific derogations such as in relation to certain selling arrangements. ${ }^{59}$ The EU legislator could indeed consider to leave some kinds of commercial practices, such as sale below cost, outside the scope of the harmonised UCP rules, since Member States are far from reaching any consensus in the regulation of such practices and since such practices - at least in the retail sector - have no or very limited cross-border dimension. ${ }^{60}$ In this way, positive and negative harmonization would be again identical in scope and would constitute a reflection of each other. The unlikely and undesirable alternative would be to blacklist sale below cost.

55 Report on Regulation 1/2003, 6-7.

56 See also E. Morgan De Rivery and F. Amato, 'The System of Interplay between EC and National Laws as Laid Down in Article 3', in M. Merola and D. Waelbroeck (eds.), Towards an Optimal Enforcement of Competition Law in Europe (2010) 131, at 143.

57 Staff Working Paper accompanying the Report on Regulation 1/2003, 54-55, referring to inter alia U.K. Office of Fair Trading, 'Supermarkets: The Code of Practice and Other Competition Issues, Conclusions' (August 2005); OECD Roundtable on Resale Below Cost Laws and Regulations, Note by the Secretariat, Directorate for Financial and Enterprise Affairs, Competition Committee, 22 September 2005.

58 The above-mentioned study on the impact of national rules on unilateral conduct that diverge from Article 102 TFEU will also give an explanation and quantification of the impact of a possible extension of the convergence rule to national competition laws concerning unilateral conduct on undertakings.

59 See Keirsbilck, above n. 23.

60 See Written parliamentary question by E. Turunen, MEP (Verts/ALE) to the Commission, 2 July 2010, E-4844/10, whether the Commission intends to revise the UCP Directive with a view to allowing Member States to maintain or introduce national rules in those areas which were included in the SP Proposal so that consumers are ensured with a high level of protection and Answer given by V. Reding on behalf of the Commission, 9 August 2010, E-4844/2010; Written parliamentary question by E. Turunen, MEP (Verts/ ALE) to the Commission, 4 October 2010, E-7909/10 and Answer given by V. Reding on behalf of the Commission, 25 November 2010, E-7909/2010; Written parliamentary question by C. Schaldemose, MEP (S\&D) to the Commission, 7 December 2010, E-010017/2010 and Answer given by V. Reding on behalf of the Commission, 2 February 2011, E-010017/2010. 